\title{
Influence of CCA-A Preservative on Physical-mechanical Properties of Brazilian Tropical Woods
}

\author{
Andréa de Souza Almeida, ${ }^{\mathrm{a}, *}$ Gabriel Criscuolo, ${ }^{\text {a }}$ Tiago Hendrigo de Almeida, ${ }^{\mathrm{a}}$ \\ André Luis Christoforo, ${ }^{\mathrm{b}}$ Eduardo Chahud, ${ }^{\mathrm{c}}$ Luiz A. M. N. Branco, ${ }^{\mathrm{d}}$ \\ Roberto V. Pinheiro, ${ }^{e}$ and Francisco Antonio Rocco Lahr ${ }^{f}$
}

\begin{abstract}
Fast-growing species are gradually being used more in the Brazilian timber market. Such species are more susceptible to deterioration and require conservative treatment to prolong their service life. This work analyzed the influence of the chromated copper arsenate oxide (CCA-A) treatment on the physical-mechanical properties of the tropical woods Simarouba amara (C20), Cedrelinga catenaeformis (C30), and Erisma uncinatum (C40), which were chosen to cover the three lower strength classes, as prescribed by Brazilian Standard Norm. The CCA-A was applied to the wood with the vacuum-pressure process, which could increase the amount of surface defects and weaken the wood properties. To investigate the influence of this process, complete characterization of the species with and without CCA-A was performed, and a Tukey's multiple comparisons test ( $5 \%$ significance level) was applied. Also, scanning electron microscopy (SEM) images and energy dispersive spectra (EDS) were obtained to investigate the behavior of the preservative at the cellular level. Through the obtained results, it was concluded that the CCA did not affect the physical-mechanical properties of the studied species.
\end{abstract}

Keywords: Tropical woods; Physical-mechanical properties; Treatment of wood; CCA preservative

Contact information: a: Department of Science and Materials Engineering, University of São Paulo, Av. Trabalhador São Carlense 400, São Carlos, SP 13566-590 Brazil; b: Department of Civil Engineering, Federal University of São Carlos, Rodovia Washington Luís km 235-SP310, São Carlos, SP 13565-905 Brazil; c: Department of Civil Engineering, Federal University of Minas Gerais (UFMG), Belo Horizonte, Brazil; d: Department of Civil Engineering, FUMEC University, Belo Horizonte, Brazil; e: Department of Civil Engineering, Mato Grosso State University (UNEMAT), Sinop, Brazil; f: Department of Structures, University of São Paulo, Av. Trabalhador São Carlense 400, São Carlos, SP 13566-590 Brazil;

*Corresponding author:andreadsa.engcivil@gmail.com

\section{INTRODUCTION}

Brazil shows a great inclination for trade in tropical timber (da Silva and Filho 2015), with emphasis on species that have unique mechanical and aesthetic properties and are important to the construction industry. They are preferred for manufacturing a variety of products, such as furniture, cabinets, and architectural works. To meet the growing wood demand for construction and production of furniture, physical and mechanical properties of tropical species and recommended preservative treatments have been the focus of much research in recent decades (Darmawan et al. 2012; Dadzie et al. 2016; Jankowska et al. 2017).

The physical-mechanical properties of wood assist as a reference for the classification of wood and are strong indicators of the quality of each species. They provide information that helps manufacturers better understand their potential use (Faria 
et al. 2015; Dadzie et al. 2016). However, in Brazil the exploitation of wood, even in areas with certification, is often performed without the application of sustainable production criteria or proper planning (da Silva and Filho 2015). In general, this is a result of a lack of knowledge of the wood physical-mechanical properties and performance under different service conditions (Segundinho et al. 2013).

Wood is a versatile material with advantages over other materials, such as concrete, steel, aluminum, and plastic. Among these advantages are the strong relationship between the mechanical strength and density, low energy consumption during production, its status as a renewable resource, and good thermal and electrical insulation (Kollmann and Côté 1968; Vidal et al. 2015; Hodoušek et al. 2017; Osuji and Nwankwo 2017; de Almeida et al. 2018). However, wood is composed of a relatively hydrophobic matrix and hydrophilic fibers, which makes its use less disseminated because of its susceptibility to wood-deteriorating organisms (Mohan et al. 2008; Temiz et al. 2010; 2013; Ferrarini et al. 2012).

The deterioration of wood is caused by xylophagous organisms, which use wood as a source of food and housing. This deterioration drastically decreases the strength properties of wood, which creates a challenge in controlling and analyzing various factors, in addition to the physical-chemical factors, that have a potential impact on the useful life of wood (Edlund and Nilsson 1998; Isaksson et al. 2013). The association between the different factors that cause wood deterioration and its strength properties has been the focus of research that predicts the length of the useful life and performance of wood in service (van de Kuilen 2007; Brischke and Meyer-Veltrup 2016).

To extend the service life of wood, many processes that use chemicals have been developed. Water-soluble preservative products are the most used and make wood more resistant to xylophagous organisms (Boschetti et al. 2016). In Brazil, the most commonly used wood preservatives in chemical treatments are chromated copper borate (CCB) and chromated copper arsenate (CCA), the latter of which is used in $80 \%$ of treated wood production (de Souza 2013; Icimoto et al. 2013; Ferro et al. 2014).

The United States Environmental Protection Agency (EPA), which is the agency responsible for environmental product management in the United States, has concluded that CCA poses no danger to human health when used in wood in its most stable form (oxide); once reacted, it is not easily released from wood. As a precautionary measure, the EPA has restricted the use of wood treated with CCA for some non-residential uses and restricted continuous contact with people. In Brazil, its use has not yet been restricted (Kear et al. 2008; Vidal et al. 2015).

Because of the high consumption of wood species with a high natural durability, these species have become scarce and the supplies are in intense decline in many regions. As a solution, fast-growing tropical species that have a medium to low density are gradually being used more in the Brazilian timber market. However, such species are more susceptible to deterioration and require conservative treatment (Paes et al. 2001; Lopes et al. 2017). The main wood products in Brazil that are subject to this treatment include fence posts (with great representation in rural areas), poles, crosses, wooden crossties, and structures for civil construction (Chagas et al. 2015).

In this study, the influence of impregnation against biological demand was analyzed with CCA-A on the physical-mechanical properties of the tropical wood species caixeta (Simarouba amara, C20), cedroarana (Cedrelinga catenaeformis, C30), and cambará (Erisma uncinatum, C40). These were chosen to represent the three lower strength classes, according to what is prescribed in ABNT NBR 7190 (1997): Design of 
wooden structures. If the influence is confirmed, it will be necessary to adopt a new coefficient of modification of the strength in wooden structural elements based on the requirements of Brazilian Standard Norm.

\section{EXPERIMENTAL}

\section{Materials}

In this work, three species of Brazilian tropical timbers were analyzed: Simarouba amara, Cedrelinga catenaeformis, and Erisma uncinatum, which are known as caixeta (C20), cedroarana (C30), and cambará (C40), respectively. These wood species are common among the tropical wood species used in general civil construction and were chosen to represent the three lower timber strength classes. This was prescribed by ABNT NBR 7190 (1997), which divides wood into strength classes with the purpose of using wood with standard properties to aid choosing the wood type for structural projects.

The three lower strength classes for the dicotyledons are C20, C30, and C40, which have the characteristic values of the resistance to compression parallel to the fibers equal to 20,30, and $40 \mathrm{MPa}$, respectively.

Caixeta and cedroarana woods do not have a good natural resistance to the attack of xylophagous organisms. The heartwood and sapwood of cedroarana are difficult to treat with water-soluble preservative products, even when treated under pressure. Cambará, also called cedrinho, has low resistance to the attack of xylophagous organisms. The sapwood and heartwood are easy to preserve when subjected to pressure treatments (IPT 2017).

The lot of cambará woods was purchased from the Abel Madeiras logging company (São Carlos, Brazil), and the caixeta and cedroarana lots were purchased from Madeireira do Cesar (Brotas, Brazil). To complete the three lots used in this research (one for each species), three partial purchases were made, at different times, until the required amount of material was reached.

\section{Methods}

The wood used in this work was treated with CCA-A (oxide), provided by Ferrari Tratamento de Madeiras (São Carlos, Brazil), using the vacuum-pressure method with a pressure between $12 \mathrm{~atm}$ and $14 \mathrm{~atm}$ and a retention of $9.6 \mathrm{~kg}$ of preservative. $\mathrm{m}^{-3}$ of treated wood. The CCA is used in three different types of formulations (types A, B, and C). All formulations contain about $19 \%$ of copper oxide $(\mathrm{CuO})$ and differ in relation to chromium and arsenic contents, as shown in Table 1.

Table 1. Composition of CCA (\%)

\begin{tabular}{|c|ccc|}
\hline Component & Type A & Type B & Type C \\
\hline Chrome as $\mathrm{CrO}_{3}$ & 65,5 & 35,3 & 47,5 \\
Copper as Cuo & 18,1 & 19,6 & 18,5 \\
Arsenic as $\mathrm{As}_{2} \mathrm{O}_{5}$ & 16,4 & 45,1 & 34,0 \\
\hline
\end{tabular}

Adapted from LEPAGE (1986)

\section{Physical-mechanical properties and application of Tukey's test}

The tests were performed at the Wood Laboratory and Timber Structures, Department of Structural Engineering (SET), School of Engineering of Sao Carlos 
(Brazil). Figure 1 shows the nominal dimensions of the wood species from which samples were taken for testing. For each wood species, 12 pieces with the cross-section dimensions $16 \mathrm{~cm} \times 6 \mathrm{~cm}$ and a length of $1.5 \mathrm{~m}$ for each treated section (with and without CCA treatment) were necessary for the preparation of the specimens used in the determination of the properties, which were prepared in accordance with the requirements of Annex B of ABNT NBR 7190 (1997).

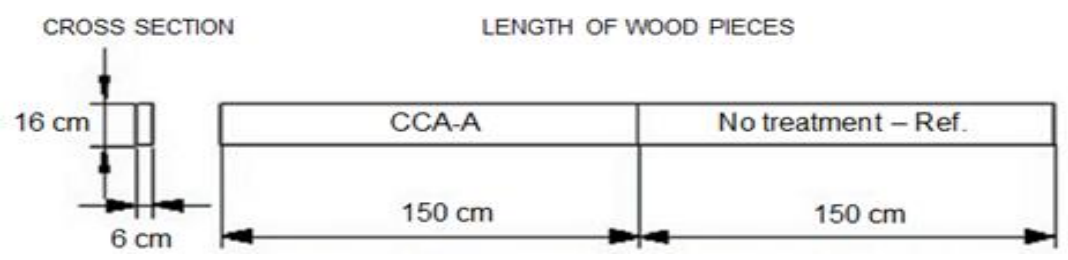

Fig. 1. Dimensions of the samples for the tests

The physical-mechanical properties of the wood were determined as recommended in ABNT NBR 7190 (1997). For the mechanical tests, an AMSLER universal testing machine (Schaffhausen, Switzerland) with a $250-\mathrm{kN}$ capacity was used. The toughness tests were performed with this machine as well.

First, the complete characterization of the untreated species was performed; afterwards, the complete characterization of the species treated with the CCA-A preservative was done. The results of the strength and stiffness properties were corrected for a standard reference moisture content of 12\%, as established by ABNT NBR 7190 (1997).

The properties investigated were the apparent density at a $12 \%$ moisture content $\left(\rho_{\text {ap }}\right)$, compressive strength parallel to the grain $\left(f_{\mathrm{c} 0}\right)$, modulus of elasticity parallel to the grain $\left(E_{\mathrm{c} 0}\right)$, compressive strength perpendicular to the grain $\left(f_{\mathrm{c} 90}\right)$, tensile strength parallel to the grain $\left(f_{\mathrm{t} 0}\right)$, modulus of elasticity in tension parallel to the grain $\left(E_{\mathrm{t} 0}\right)$, tensile strength normal to the grain $\left(f_{\mathrm{t} 90}\right)$, conventional strength in the static bending test $\left(f_{\mathrm{M}}\right)$, conventional modulus of elasticity in the static bending test $\left(E_{\mathrm{M}}\right)$, hardness parallel to the grain $\left(f_{\mathrm{H} 0}\right)$, hardness normal to the grain $\left(f_{\mathrm{H} 90}\right)$, shear strength parallel to the grain $\left(f_{\mathrm{v}}\right)$, and toughness $(W)$.

It should be noted that 12 specimens were produced for each species, test, and experimental condition (without and with CCA treatment), which resulted in 936 specimens in total.

The influence of the treatment factor (without (reference) and with CCA) on the physical and mechanical properties of the wood species was evaluated using Tukey's test at a 5\% significance level. In Tukey's test, A denotes the experimental condition with the highest mean property value, $\mathrm{B}$ denotes the experimental condition associated with the second highest mean value, and so on. The same letter implied the treatments had statistically equivalent means.

Scanning electron microscopy and energy dispersive spectroscopy

The scanning electron microscopy (SEM) and energy dispersive spectroscopy (EDS) tests were done only with the $S$. amara species because it is the most porous species, and consequently provided a better analysis of the location and fixing of the preservative solution in the wood cells (in the lumen and cell wall). Both tests were 
performed at the Center of Instrumental Chemical Analysis of the Institute of Chemistry of São Carlos (Brazil).

Scanning electron microscopy images were obtained using a ZEISS LEO 440 electronic microscope (Cambridge, England) with an OXFORD detector (model 7060, Abingdon, England) operating with a $20-\mathrm{kV}$ electron beam, 2.82-A current, and 200-pA probe. The samples were covered with $6 \mathrm{~nm}$ of gold using a BAL-TEC MED 020 metallizer coating system (BAL-TEC, Balzers, Liechtenstein) and kept in a desiccator until analysis. The metallization conditions were a chamber pressure of $2.00 \times 10^{-2} \mathrm{mbar}$, current of $60 \mathrm{~mA}$, and deposition rate of $0.60 \mathrm{~nm} . \mathrm{s}^{-1}$.

The EDS test was performed on an EDX LINK ANALYTICAL machine (Isis System Series 300, Abingdon, England), with a SiLi Pentafet detector (Oxford Instruments, Abingdon, England), ATW II (Atmosphere Thin Window, Oxford Instruments, Abingdon, England), resolution of $13.3 \mathrm{eV}$ at $5.9 \mathrm{keV}$ and area of $10 \mathrm{~mm}^{2}$, and coupled with a ZEISS LEO 440 electronic microscope. The co-standard for calibration was a $20-\mathrm{kV}$ electron beam, 25-mm focal length, 30\% dead time, 2.82-A current, and I probe of $2.5 \mathrm{nA}$.

\section{RESULTS AND DISCUSSION}

\section{Physical-mechanical Properties and Application of Tukey's Test}

The experimental average values $(\overline{\mathrm{x}})$ and Tukey's test results for the analyzed properties (without (reference) and with CCA) for the three wood species are shown in Table 2. The coefficients of variation (CV) are shown in Table 3, and the mean values from the literature for the strength and fracture toughness properties of E. uncinatum are shown in Table 4.

Table 2. Experimental Mean Values Obtained for the Analyzed Properties and Tukey's Test for the Studied Species

\begin{tabular}{|c|c|c|c|c|c|c|c|c|c|c|c|c|}
\hline Speci & \multicolumn{4}{|c|}{ S. amara } & \multicolumn{4}{|c|}{ C. catenaeformis } & \multicolumn{4}{|c|}{ E. uncinatum } \\
\hline \multirow{2}{*}{ Property } & \multicolumn{2}{|c|}{ Reference } & \multicolumn{2}{|c|}{ With CCA } & \multicolumn{2}{|c|}{ Reference } & \multicolumn{2}{|c|}{ With CCA } & \multicolumn{2}{|c|}{ Reference } & \multicolumn{2}{|c|}{ With CCA } \\
\hline & $\bar{x}$ & $\mathrm{~T}$ & $\bar{x}$ & $\mathrm{~T}$ & $\bar{x}$ & $\mathrm{~T}$ & $\bar{x}$ & $\mathrm{~T}$ & $\bar{x}$ & $\mathrm{~T}$ & $\bar{x}$ & $\mathrm{~T}$ \\
\hline$\rho_{\mathrm{ap}}(\mathrm{g}$ & 0.33 & A & 0.34 & & 0.54 & & 0.55 & & 0.73 & A & 0.68 & A \\
\hline$f_{\mathrm{co}}(\mathrm{M}$ & 34.47 & A & 04 & 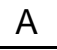 & 1.36 & 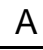 & 41.41 & & 70.01 & A & 69.27 & A \\
\hline$E_{\mathrm{c} 0}(\mathrm{MPa})$ & 7325 & A & 7736 & A & 9352 & A & 8932 & A & 14403 & A & 13362 & A \\
\hline$f_{\mathrm{c} 90}(\mathrm{MPa})$ & 7.20 & A & .07 & A & 4.54 & A & 4.69 & & 7.20 & A & 7.07 & A \\
\hline$f_{\mathrm{t} 0}(\mathrm{Ml}$ & 49.48 & $A B$ & 46.14 & B & 67.20 & A & 73.20 & A & 68.22 & A & 72.28 & A \\
\hline$E_{\mathrm{t} 0}(\mathrm{~N}$ & 9414 & $A$ & 9920 & A & 7527 & 10 & 8836 & & 13611 & A & 13947 & A \\
\hline$f_{\text {t90 }}(\mathrm{MPa})$ & 2.46 & $A B$ & 2.16 & $B$ & 4.35 & A & 4.22 & A & 2.62 & A & 2.26 & $A B$ \\
\hline$f_{\mathrm{M}}(\mathrm{MPa})$ & 62.36 & A & 62.07 & A & 71.43 & A & 77.14 & A & 97.06 & A & 98.91 & A \\
\hline$E_{\mathrm{M}}(\mathrm{MPa})$ & 8858 & A & 9378 & A & 11048 & A & 12395 & 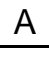 & 15601 & A & 14426 & A \\
\hline$f_{\mathrm{H} 0}(\mathrm{MPa})$ & 9.16 & A & 484.39 & A & 508.98 & A & 583.47 & $n$ & 79.58 & A & 86.75 & A \\
\hline$f_{\mathrm{H} 90}(\mathrm{MPa})$ & 283.33 & $A$ & 305.20 & A & 346.06 & A & 372.58 & A & 51.50 & A & 49.75 & A \\
\hline$f_{v}(\mathrm{MPa})$ & 8.56 & B & 10.86 & A & 10.44 & A & 11.28 & A & 12.48 & A & 13.01 & A \\
\hline$W(\mathrm{Nm})$ & 15.37 & $B$ & 25.26 & A & 62.85 & A & 69.31 & A & 55.24 & A & 48.87 & $A B$ \\
\hline
\end{tabular}

$\overline{\mathrm{X}}$ - Experimental mean values; $\mathrm{T}$ - Tukey's test values 
Table 3. Coefficients of Variation (CV) for Each Property

\begin{tabular}{|c|c|c|c|c|c|c|}
\hline Species & \multicolumn{2}{|c|}{ S. amara } & \multicolumn{2}{c|}{ C. catenaeformis } & \multicolumn{2}{c|}{ E. uncinatum } \\
\hline \multirow{2}{*}{ Property } & Reference & With CCA & Reference & With CCA & Reference & With CCA \\
\cline { 2 - 7 } & Cv $(\%)$ & Cv $(\%)$ & Cv $(\%)$ & Cv $(\%)$ & Cv $(\%)$ & Cv $(\%)$ \\
\hline$\rho_{\mathrm{ap}}\left(\mathrm{g} / \mathrm{cm}^{3}\right)$ & 2.67 & 1.95 & 10.24 & 2.16 & 9.89 & 8.57 \\
\hline$f_{\mathrm{c} 0}(\mathrm{MPa})$ & 15.49 & 11.50 & 15.49 & 11.50 & 14.99 & 11.50 \\
\hline$E_{\mathrm{co} 0}(\mathrm{MPa})$ & 29.71 & 28.04 & 28.20 & 22.03 & 20.30 & 22.30 \\
\hline$f_{\mathrm{c} 90}(\mathrm{MPa})$ & 14.99 & 11.50 & 7.86 & 8.73 & 15.06 & 11.19 \\
\hline$f_{\mathrm{t} 0}(\mathrm{MPa})$ & 7.41 & 13.22 & 30.16 & 35.58 & 32.10 & 25.16 \\
\hline$E_{\mathrm{t} 0}(\mathrm{MPa})$ & 7.02 & 19.09 & 16.62 & 18.95 & 22.31 & 15.61 \\
\hline$f_{\mathrm{t} 90}(\mathrm{MPa})$ & 25.60 & 34.24 & 23.55 & 16.64 & 23.60 & 25.20 \\
\hline$f_{\mathrm{M}}(\mathrm{MPa})$ & 15.03 & 12.04 & 34.13 & 14.04 & 19.58 & 12.85 \\
\hline$E_{\mathrm{M}}(\mathrm{MPa})$ & 17.85 & 20.61 & 26.49 & 13.90 & 24.88 & 15.07 \\
\hline$f_{\mathrm{H} 0}(\mathrm{MPa})$ & 14.04 & 26.67 & 29.43 & 25.56 & 10.42 & 8.90 \\
\hline$f_{\mathrm{H} 90}(\mathrm{MPa})$ & 15.19 & 41.00 & 29.67 & 45.77 & 9.84 & 6.00 \\
\hline$f_{\mathrm{v}}(\mathrm{MPa})$ & 17.39 & 15.71 & 21.21 & 9.85 & 18.02 & 15.77 \\
\hline$W(\mathrm{Nm})$ & 22.11 & 17.59 & 49.34 & 23.81 & 23.42 & 11.14 \\
\hline
\end{tabular}

Table 4. Mean Values from the Literature for the Strength and Fracture Toughness Properties of $E$. uncinatum (Cambará)

\begin{tabular}{|c|c|c|c|c|c|c|c|}
\hline Property & $f_{\mathrm{c} 0}(\mathrm{MPa})$ & $f_{\mathrm{c} 90}(\mathrm{MPa})$ & $f_{\mathrm{t} 0}(\mathrm{MPa})$ & $f_{\mathrm{t} 90}(\mathrm{MPa})$ & $f_{\mathrm{M}}(\mathrm{MPa})$ & $f_{\mathrm{v}}(\mathrm{MPa})$ & $f_{\mathrm{s}}(\mathrm{MPa})$ \\
\hline$\overline{\mathrm{x}}$ & 34 & 7.0 & 45 & 4.9 & 63 & 14 & 0.8 \\
\hline Property & $E_{\mathrm{c} 0}(\mathrm{MPa})$ & $E_{\mathrm{t} 0}(\mathrm{MPa})$ & $E_{\mathrm{M}}(\mathrm{MPa})$ & $\rho_{\mathrm{ap}}\left(\mathrm{g} / \mathrm{cm}^{3}\right)$ & $f_{\mathrm{H} 0}(\mathrm{MPa})$ & $f_{\mathrm{H} 90}(\mathrm{MPa})$ & $W(\mathrm{Nm})$ \\
\hline$\overline{\mathrm{x}}$ & 12967 & 12764 & 12376 & 0.68 & 51 & 67.00 & 33.39 \\
\hline
\end{tabular}

Adapted from Lahr et al. (2016)

From Tukey's test, the CCA preservative significantly increased the $f_{\mathrm{v}}$ and $\mathrm{W}$ of $S$. amara. For the other properties of this species, the use of the preservative did not influence its values. There was no loss of resistance because of the preservative treatment. From Tukey's test, the CCA preservative did not significantly decrease the strength, stiffness, and $W$ values of the cedroarana wood.

Most values obtained experimentally for the $S$. amara and $C$. catenaeformis properties were consistent with the values found by Institute for Technological Research (2017). Because wood is a biological material, it may present variable physical and mechanical properties within the same species depending on the wood lot analyzed (Segundinho et al. 2017). Thus, differences in the properties were possibly the result of tests with different wood lots of the same species.

Several databases, electronic journals, libraries, and social networks were consulted, but no research was found that addressed the complete characterization of the $S$. amara and $C$. catenaeformis species or possible losses in property values of these wood species from conservative treatment with CCA. Because of the pioneering nature of the research, no further comparisons were possible. 
The apparent density for E. uncinatum species after treatment with CCA was equal to the value in Table 4 . The $f_{\mathrm{c} 0}$ and modulus of elasticity values obtained in this work for the two treatment conditions were considerably higher than the values in Table 4. The same applied to the $f_{\mathrm{t} 0}, f_{\mathrm{H} 0}, f_{\mathrm{M}}$, and $W$.

The values that were obtained experimentally in this work for the $f_{\mathrm{t} 90}, f_{\mathrm{v}}$, and $f_{\mathrm{H} 90}$ were lower than those in Table 4 . The $f_{\mathrm{c} 90}$ obtained for the two treatment conditions were close to the values in the literature. From Tukey's test, the CCA preservative significantly reduced the $f_{\mathrm{t} 90}$ and $W$ values. These properties that had their values reduced were due to the fragile rupture and to the very anatomy of the wood. The chemical treatment did not significantly affect the values of the other properties of the cambará wood.

No further studies were found that included the complete characterization of the Erisma uncinatum, nor any research that dealt with the influence of impregnation against biological demand on the mechanical properties of this species.

Other researchers have been analyzing the behavior of other wood species after the chemical treatment, as Faria et al. (2015), who analyzed the influence of CCA preservation on the physical-mechanical properties of Eucalyptus camaldulensis wood, and concluded that the treated wood presented improvements in the values of the properties analyzed.

Ferreira et al. (2017) analyzed the influence of the chemical treatment with CCA on the conventional strength in the static bending test in wood panels of Pinus taeda and concluded that the treatment increased the moisture content of the panel and decreased its mechanical strength.

Segundinho et al. (2017) studied the efficiency of the bonding of treated wood of Eucalyptus cloeziana for the production of glued laminated wood and concluded that CCA interfered negatively in the properties of basic density and shear strength parallel to the fibers.

The variability of the results in this area shows the great number of variables (such as species, final application of wood, strength class) and the need to reach more precise results with researches that aim to analyze the influence of chemical treatment on Brazilian tropical wood species.

Scanning electron microscopy and energy dispersive spectroscopy

Figure 2 shows an image generated by SEM of a crude surface, where the CCA-A was applied in the form of a solution of oxide diluted in water.

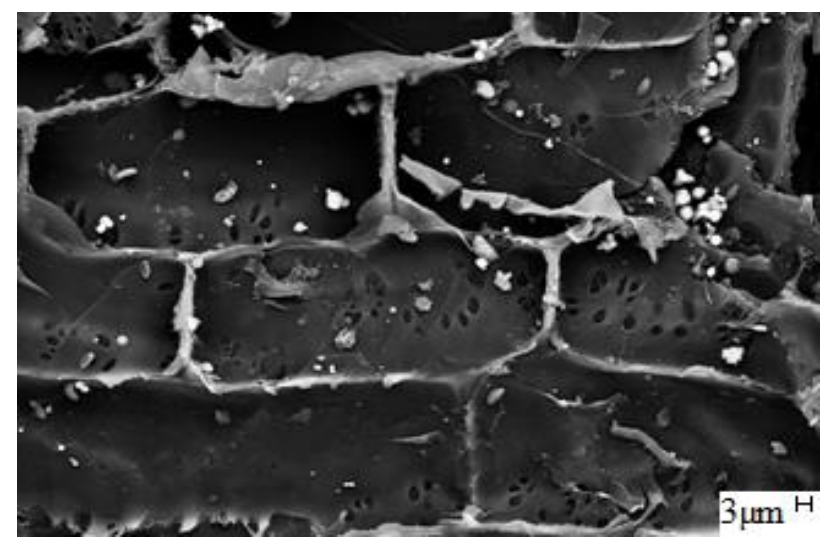

Fig. 2. SEM image with 2500 times magnification of Caixeta wood cells with CCA 
As the surface was in its raw state, the SEM analysis was performed in a punctual way. The region that was chosen had the best visualization of the cells, incorporation of the pure oxides in the cell wall, and visualization of the cell lumen.

In general, copper was fixated first by ion exchange, and then chromium fixation began with the formation of complexes of lignin acid-chromic and copper lignin chromate. The main reaction in the process was the reduction of hexavalent chromium $(+\mathrm{VI})$ to trivalent chromium (+III), which is insoluble in water. Finally, the chromium reacted with the arsenic, which formed $\mathrm{CrAsO}_{4}$. This result showed that the precipitation reactions and inorganic complexes occurred in the wood cell wall, which made the product practically insoluble (Lepage 1986; Wong and Lai 2006; Amaral 2012).

The pure oxides may be visualized in the form of crystals, which adhered mostly to the cell wall, while some dispersed in the lumen. Such crystals are detached in relation to the components of the pure wood because of the filter used in the test. This made them lighter and indicated the presence of metallic elements, such as chromium and copper, and semimetallic elements such as arsenic, which are the bases of the CCA-A preservative. Figure 3 shows the EDS spectrum.

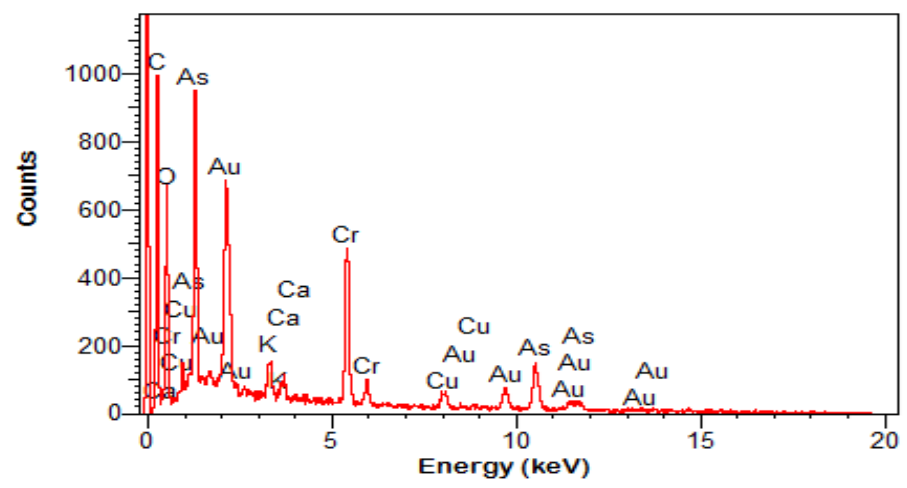

Fig. 3. EDS spectrum of the cellular structure after treatment with CCA

Based on the EDS analysis and accounting for the crystalline geometry, the light dots were determined to be pure oxide crystals adhered to the lumen and cell wall. The concentrations of other elements, such as potassium $(\mathrm{K})$, calcium $(\mathrm{Ca})$, oxygen $(\mathrm{O})$, and carbon (C), that appeared in the EDS spectrum were related to the composition of the wood itself and were expected. Gold $(\mathrm{Au})$ appeared because of the metallization of the sample to help with conduction. The adhesion of the preservative to the lumen and cell wall was not enough to alter the physical and mechanical properties because the process was not aggressive, did not increase the amount of surface defects in the wood.

\section{CONCLUSIONS}

1. The wood preservation process with CCA did not significantly decrease the physicalmechanical properties of the three evaluated tropical wood species. As the influence of the CCA was not confirmed, it will not be necessary to adopt a coefficient of modification for the strengths in structural wood elements, based on the requirements of ABNT NBR 7190 (1997).

2. The results obtained can be expanded on with new studies that cover a larger number of species and chemical treatments with other preservatives. 


\section{ACKNOWLEDGMENTS}

This study was financed in part by the Coordenação de Aperfeiçoamento de Pessoal de Nível Superior - Brasil (CAPES) (Finance Code 001). The authors thank CAPES for all of the support provided.

\section{REFERENCES CITED}

ABNT NBR 7190 (1997). "Design of wooden structures," Brazilian Association of Technical Standards, Rio de Janeiro, Brazil.

Amaral, L. S. (2012). Penetração e Retenção do Preservante em Eucalyptus com Diferentes Diâmetros [Penetration and Retention of Eucalyptus Preservative with Different Diameters], Master's Thesis, Universidade Federal de Lavras, Lavras, Brazil.

Boschetti, W. T. N., Vieira, D. M., Moulin, J. C., Lopes, D. J. V., Paes, J. B., and Carvalho, A. M. M. L. (2016). "Preservative treatment of fence posts evaluation through photocolorimetry segmentation performance," Rev. Arvore 40(4), 731-739. DOI: $10.1590 / 0100-67622016000400017$

Brischke, C., and Meyer-Veltrup, L. (2016). "Modelling timber decay caused by brown rot fungi," Mater. Struct. 49(8), 3281-3291. DOI: 10.1617/s11527-015-0719-y

Chagas, S. F., Evangelista, W. V., Silva, J. d. C., and Pinheiro, M. A. (2015). "Estudo da retenção e penetração de CCA na madeira de teca, visando uso como mourões tratados [Study of the retention and penetration of CCA in teakwood, for use as treated fence posts]," Sci. For. 43(105), 155-165.

de Almeida, T. H., de Souza, A. M., Martins, A. S. M., Christoforo, A. L., de Almeida, D. H., and Lahr, F. A. R. (2018). "Effect of service of temperature on shear strength of Pinus wood for roof structures," Acta Sci.-Technol. 40(1). DOI: 10.4025/actascitechnol.v40i1.30913

da Silva, R. P., and Filho, J. V. C. (2015). "Minimização dos custos de transporte para exportação de madeira da Amazônia Legal [Minimization of transport costs for the exportation of wood from the Legal Amazon]," Revista de Administração e Negócios da Amazônia 7(1), 103-125. DOI: 10.18361/2176-8366/rara.v7n1p103-125

Dadzie, P. K., Amoah, M., Frimpong-Mensah, K., and Oheneba-Kwarteng, F. (2016).

"Some physical, mechanical and anatomical characteristics of stemwood and branchwood of two hardwood species used for structural applications," Mater. Struct. 49(12), 4947-4958. DOI: 10.1617/s11527-016-0835-3

Darmawan, W., Rahayu, I., Nandika, D., and Marchal, R. (2012). "The importance of extractives and abrasives in wood material on the wearing of cutting tools," BioResources 7(4), 4715-4729. DOI: 10.15376/biores.7.4.4715-4729

de Souza, A. M. (2013). Production and Performance Evaluation of Pinus sp Oriented Strandboard (OSB) with Metallic Gauze Inclusion, Master's Thesis, University of São Paulo, São Carlos, Brazil.

Edlund, M.-L., and Nilsson, T. (1998). "Testing the durability of wood," Mater. Struct. 31(9), 641-647. DOI: 10.1007/BF02480616

Faria, W. S., Resende, D. R., Guimarães, I. L., Protássio, T. d. P., and Guimarães Junior, J. B. (2015). “Avaliação das propriedades físico-mecânicas da madeira de Eucalyptus camaldulensis tratado e não tratado com preservativo [Evaluation of physicalmechanical properties of Eucalyptus camaldulensis wood treated and not treated with 
preservative]," Enciclopédia Biosfera 11(21), 287-293.

Ferrarini, S. F., dos Santos, H. S., Miranda, L. G., Azevedo, C. M. N., Pires, M. J. R., and Maia, S. M. (2012). "Classificação de resíduos de madeira tratada com preservativos de madeira tratada à base de arseniato de cobre cromatado e boro/flúor [Classification of waste wood treated with chromated copper arsenate and boron/fluorine preservatives]," Quím. Nova 35(9), 1767-1771. DOI: 10.1590/S010040422012000900012

Ferreira, B. S., Silva, J. V. F., and Campos, C. I. (2017). "Static bending strength of heattreated and chromated copper arsenate-treated plywood," BioResources 12(3), 62766282. DOI: 10.15376/biores.12.3.6276-6282

Ferro, F. S., Icimoto, F. H., de Almeida, D. H., Christoforo, A. L., and Lahr, F. A. R. (2014). "Influence of preservative type in mechanical properties of OSB panels," in: Proceedings of WCTE 2014 - World Conference on Timber Engineering, Quebec, Canada.

Hodoušek, M., Dias, A. M. P. G., Martins, C., Marques, A. F. S., and Böhm, M. (2017). "Comparison of non-destructive methods based on natural frequency for determining the modulus of elasticity of Cupressus lusitanica and Populus $x$ canadensis," BioResources 12(1), 270-282. DOI: 10.15376/biores.12.1.270-282

Icimoto, F. H., Ferro, F. S., Varanda, L. D., de Souza, A. M., de Almeida, D. H., Christoforo, A. L., and Lahr, F. A. R. (2013). "Physical and mechanical properties of Paricá wood species treated with CCB preservative," International Journal of Materials Engineering 3(4), 82-86. DOI: 10.5923/j.ijme.20130304.03

Instituto de Pesquisas Tecnológicas (2017). "Wood information," (http://www.ipt.br/ consultas_online/informacoes_sobre_madeira/busca), Accessed 15 Mar 2017.

Isaksson, T., Brischke, C., and Thelandersson, S. (2013). "Development of decay performance models for outdoor timber structures," Mater. Struct. 46(7), 1209-1225. DOI: $10.1617 / \mathrm{s} 11527-012-9965-4$

Jankowska, A., Drożdżec, M., Sarnowski, P., and Horodeński, J. (2017). “Effect of extractives on the equilibrium moisture content and shrinkage of selected tropical wood species," BioResources 12(1), 597-607. DOI: 10.15376/biores.12.1.597-607

Kear, G., Wú, H.-Z., and Jones, M. S. (2008). "Corrosion of ferrous- and zinc-based materials in CCA, ACQ and CuAz timber preservative aqueous solutions," Mater. Struct. 41(8), 1405-1417. DOI: 10.1617/s11527-007-9338-6

Kollmann, F. F. P., and Côté Junior, W. A. (1968). Principles of Wood Science and Technology, Springer Verlag, Berlin, Germany.

Lahr, F. A. R., Arroyo, F. N., de Almeida, T. H., de Almeida Filho, F. M., Mendes, I. S., and Christoforo, A. L. (2016). "Full characterization of Erisma uncinatum Warm wood species," International Journal of Materials Engineering 6(5), 147-150. DOI: 10.5923/j.ijme.20160605.01

Lepage, E. S. (1986). "Preservativos e sistemas preservativos [Preservatives and Preservatives Systems]," in: Manual de Preservação de Madeiras [Manual of Preservation of Wood], Instituto de Pesquisas Tecnológicas do Estado de São Paulo, São Paulo, Brazil, pp. 279-330.

Lopes, D. J. V., Paes, J. B., Jankowsky, I. P., Segundinho, P. G. d. A., and Vidaurre, G. B. (2017). "Influências do diâmetro e umidade da madeira na qualidade do tratamento preservativo [Influences of diameter and wood moisture on quality of the preservative treatment]," Floresta e Ambiente 24. DOI: 10.1590/2179-8087.020716 
Mohan, D., Shi, J., Nicholas, D. D., Pittman Jr., C. U., Steele, P. H., and Cooper, J. E. (2008). "Fungicidal values of bio-oils and their lignin-rich fractions obtained from wood/bark fast pyrolysis," Chemosphere 71(3), 456-465. DOI:

10.1016/j.chemosphere.2007.10.049

Osuji, S. O., and Nwankwo, E. (2017). "Investigation into the physical and mechanical properties of structural wood commonly used in Nigeria: A case study of Benin City," Journal of Civil Engineering Research 7(5), 131-136. DOI: 10.5923/j.jce.20170705.01

Paes, J. B., Moreschi, J. C., and de Lelles, J. G. (2001). "Tratamento preservativo de moirões de bracatinga (Mimosa scabrella Benth.) e de Eucalyptus viminalis Lab. pelo método de imersão prolongada [Preservative treatment of Mimosa scabrella Benth. and Eucalyptus viminalis Lab. fence posts by dip-diffusion method]," Cerne 7(2), 6580 .

Segundinho, P. G. d. A., Gonçalves, F. G., Gava, G. C., Tinti, V. P., Alves, S. D., and Regazzi, A. J. (2017). "Eficiência da colagem de madeira tratada de Eucalyptus cloeziana F. Muell para produção de madeira laminada colada (MLC) [Efficiency of the glue line in the treated wood Eucalyptus cloeziana F. Muell for glued laminated (glulam) beams production]," Revista Matéria 22(2). DOI: 10.1590/s1517707620170002.0140

Segundinho, P. G. d. A., Zangiácomo, A. L., Carreira, M. R., Dias, A. A., and Lahr, F. A. R. (2013). "Avaliação de vigas de madeira laminada colada de cedrinho (Erisma uncinatum Warm.) [Evaluation of glued laminated timber beams of cedrinho (Erisma uncinatum Warm.]," Cerne 19(3), 441-449. DOI: 10.1590/S010477602013000300011

Temiz, A., Akbas, S., Panov, D., Terziev, N., Alma, M. H., Parlak, S., and Kose, G. (2013). "Chemical composition and efficiency of bio-oil obtained from giant cane (Arundo donax L.) as a wood preservative," BioResources 8(2), 2084-2098. DOI: 10.15376/biores.8.2.2084-2098

Temiz, A., Alma, M. H., Terziev, N., Palanti, S., and Feci, E. (2010). "Efficiency of biooil against wood destroying organisms," J. Biobased Mater. Bio. 4(4), 317-323. DOI: 10.1166/jbmb.2010.1092

van de Kuilen, J.-W. G. (2007). "Service life modelling of timber structures," Mater. Struct. 40(1), 151-161. DOI: 10.1617/s11527-006-9158-0

Vidal, J. M., Evangelista, W. V., Silva, J. d. C., and Jankowsky, I. P. (2015). "Preservação de madeiras no Brasil: Histórico, cenário atual e tendências [Preservation of wood in Brazil: History, current scenario and trends]," Ciênc. Florest. 25(1), 257-271. DOI: 10.1590/1980-509820152505257

Wong, A. H. H., and Lai, H. C. (2006). "Laboratory leaching tests to study the effects of post-treatment storage periods on CCA leachability and fixation in treated permeable and refractory Malaysian hardwoods," in: Proceedings of the 37th Annual Meeting of the International Research Group on Wood Protection, Tromso, Norway.

Article submitted: November 26, 2018; Peer review completed: February 3, 2019; Revised version received: February 16, 2019; Accepted: February 18, 2019; Published: February 25, 2019.

DOI: 10.15376/biores.14.2.3031-3041 